\title{
Application of Response Surface Methodology (RSM) to Optimize COD and Ammoniacal Nitrogen Removal from Leachate using Moringa and Zeolite Mixtures
}

\section{Zawawi Daud ${ }^{1 *}$, Mahmoud Hijab Abu Bakar², Mohd Arif Rosli ${ }^{1}$, Mohd Baharudin Ridzuan ${ }^{1,3}$ and Ruwaida Aliyu ${ }^{2}$}

${ }^{1}$ Centre of Advanced Research for Integrated Solid Waste Management (CARISMA). Faculty of Civil and Environmental Engineering, Universiti Tun Hussein Onn Malaysia

${ }^{2}$ School of Engineering and Engineering Technology, Modibbo Adama University of Technology Yola, Nigeria.

${ }^{3}$ Faculty of Technical and Vocational Education, Universiti Tun Hussein Onn Malaysia

Received 28 February 2018; accepted 23 April 2018, available online 01 May 2018

\begin{abstract}
This paper reported the optimization of $\mathrm{COD}$ and $\mathrm{NH}_{3}-\mathrm{N}$ reduction from a stabilised leachate by zeolite (ZE) and moringa oleifera leaf powder (MP) mixture using response surface methodology (RSM) and central composite design (CCD). Quadratic polynomial equations were obtained for the removal process. An initial experiment was conducted to establish the optimum mixed ratio between ZE:MP and resulted in a ratio of 24:16. Independent variables investigated in the subsequent optimization experiments include $\mathrm{pH}$, dosage and contact time. The results revealed that the optimal reduction of COD and $\mathrm{NH}_{3}-\mathrm{N}$ from landfill leachate was considerable at $\mathrm{pH} 5.9$, optimal time of 113 minutes and $100 \mathrm{gL}^{-1}$ of adsorbent dosage with desirability value of 0.917 . The upper limits for the actual versus predicted reduction were 70.14 against $69.13 \%$ and 86.94 against $86.55 \%$ respectively for $\mathrm{COD}$ and $\mathrm{NH}_{3}-\mathrm{N}$ which defined that the experimental values were relatively close to the predicted values. The study also revealed that ZE:MP mixture has a very high potential for the remediation of COD and $\mathrm{NH}_{3}-\mathrm{N}$ from a stabilized leachate.
\end{abstract}

Keywords: zeolite, moringa, RSM , optimization , leachate, $\mathrm{COD}$ and $\mathrm{NH}_{3}-\mathrm{N}$.

\section{Introduction}

Sanitary landfills are designed waste conservation systems encompassing high-technology processes and applied to dispense with the solid waste generated from municipal or industrial activities. In developed nations, waste disposal does not only rely on sanitary landfills but extended to concept of waste minimization such that the waste that reaches the landfill is eventually minimized. Sanitary landfills in developing countries are susceptible to problem of technological and economic constraints. landfills are predominantly built of layers of accumulated solid waste and overlaid with soil or other types of blanket materials. Landfills constitute a problem in waste disposal because they produce leachate. Leachate is generated from the biochemical reaction that occurs within the waste deposit as it undergoes physical, biological, and chemical decomposition under aerobic and anaerobic conditions[1-3]. It usually comprise of dissolved pollutants, unstable organic acids, toxicant heavy elements, and high density of organic matter, chemical oxygen demand (COD), ammonia nitrogen as well as biochemical oxygen demand (BOD), and may pose a critical threat to the environment and to public health if necessary control is not applied prior treatment; resulting in soil contamination and water bodies especially the rivers, lakes and groundwater that hold $0.016 \%, 1.5 \%$, and $22.3 \%$, of the earth's freshwater respectively. Virtually all prevailing leachate treatments incorporate high-technology processes. Such processes are considered to contribute to high initial and operational cost, generation of waste residue, and less adaptability to a wide variety of pollutants, among others. Selecting and designing a suitable leachate treatment system are difficult because of the dissimilarity in the amount and characteristics of leachate produced from landfill to landfill, especially as the landfills age [4-6]. Inconsistencies between landfill leachates are due to their hydrogeological conditions, locations, and environmental contributors. Hence, landfill leachates from different landfills and their respective treatment must be processed appropriately per the characteristics of each site $[7,8]$. Leachate treatment is necessary to prevent ground and surface water pollution although pollutant level generally decreases with landfill age.

The application of natural plant for cleansing of contaminated soil and water known as phytoremediation, has attained increasing recognition due to the added costeffective and lesser side effects than chemical or other approaches $[9,10]$. Numerous plant species have been identified and examined for their potential in reducing 
different pollutants. Among them is the reknown Moringa oleifera, which is known by numerous regional names as; murunga (Sri Lanka), zogale (Nigeria), ben aile (Cambodia), la mu (Taiwan), Kelor (Malaysia) mulangai (India) among others [9-11]. The emerging challenge is in the application of biosorbents and their mixtures for the treatment of landfill effluents.

The response surface methodology (RSM) with a multivariate function of the polynomial equation model is very eminently effective to relate the experimental data set of the optimisation system. The factorial design of the response surface analysis provides reliable information about the adsorption process interactions and saves time and materials significantly as opposed to the conventional linear optimization technique. The conventional linear optimization involves changing a parameter and fixing other variant parameters constant which is more commonly referred as one-factor-at-a-time. The methodology of RSM it assesses several variables by operating the regression statistical analysis on the independent variables to establish the most desirable overall factor surface [12-14]. Through the representation of the surface model, responses on the basis of the combined factors can be determined [14-16].

In this work, the effect of dosage, contact time, and $\mathrm{pH}$ on zeolite and Moringa oleifera leaves powder mixture, on COD and ammonia removal from leachate was examined. RSM was used in designing the experiment, developing models and to assess the most favourable conditions.. The outcome of the investigation can be used to determine the efficacy of the mixture in the remediation of contaminants from wastewater and possibly will substitute activated carbon in the wastewater treatment industry.

\section{Materials and method}

\subsection{Leachate sampling}

The leachate sample was procured from Simpang Renggam municipal landfill located at $\mathrm{N1}^{0} \quad 53 \quad 41.64$ latitude and E1030 2234.68 longitude in Kluang District of Johor. Uncontaminated 20-L high-density polyethylene bottles was utilised to manually collect the leachate at site in accordance to the method outlined by [17-18]. And then the leachate was characterized within $24 \mathrm{~h}$ according to the standard methods for the examination of water and wastewater [19].

\subsection{Preparation of Adsorbent media}

Moringa leaves was harvested from experimental plantation under the center of advanced research for integrated solid waste management (CARISMA) of the Faculty of civil and environmental engineering, universiti Tun Hussein. The leaves were washed clean with distilled water and oven dried at $38^{\circ} \mathrm{C}$ for 24 hours, then the leaves were pulverized to powder using mortar grinder model Fritsch. The moringa powder (MP) was sieved using $0.150 \mathrm{~mm}$ sieves. Natural zeolite (Mechastone brand) was obtained from Pt. Anugerahalam Sdn. Bhd., Parit Raja,
Malaysia at a retail price of about $0.4 \mathrm{RM}$ per kilogram. The zeolite (ZE) was then powdered using the grinder and then sieved to $0.150 \mathrm{~mm}$ particles size.

\subsection{Adsorption experiments}

Seven runs (for the mix ratio) and twenty (parameter optimization) runs were conducted in the current study. For each run, $100 \mathrm{~mL}$ of the raw leachate with an initial $\mathrm{COD}$ and $\mathrm{NH}_{3}-\mathrm{N}$ concentration of 1,763 and $573 \mathrm{mg} / \mathrm{L}$ respectively was introduced into a $250 \mathrm{~mL}$ Erlenmeyer flask [17]. Initial experimentation was carried to determine the optimum mix ratio between moringa and zeolite media according to the design obtained by RSM using $150 \mathrm{rpm}$ shaking speed on an orbital shaker (model Daiki) at a defined dosage (40g), $\mathrm{pH} 7$ and varied mix ratio according to the RSM design.

Further optimisation was performed using acquired optimized mix ratio and raw leachate solution at $150 \mathrm{rpm}$ agitation speed using the RSM selected $\mathrm{pH}$, dosage and contact time. After some RSM suggested time interval, samples were then taken from the flasks, filtered using $0.45 \mu \mathrm{m}$ filter membrane and analyzed for residual COD and $\mathrm{NH}_{3}-\mathrm{N}$ content [17]. The COD and $\mathrm{NH} 3-\mathrm{N}$ were assessed by the closed reflux and Nessler Method respectively using atomic adsorption spectrophotometer ( Model HACH DR6000). The effect of $\mathrm{pH}$ was studied by adjusting the $\mathrm{pH}$ of the leachate solutions using $\mathrm{HCl}$ and $\mathrm{NaOH}$ [18]. Experimental results were calculated as percentage removal of $\mathrm{COD}$ and $\mathrm{NH}_{3}-\mathrm{N}$ according to equation (1).

$$
\% \text { Removal }=\left[\left(C_{i}-C_{f}\right) / C_{t}\right] \times 100
$$

Where $C_{i}$ and $C_{f}$ are the initial and final $\operatorname{COD}(\mathrm{mg} / \mathrm{L})$ and $\mathrm{NH}_{3}-\mathrm{N}(\mathrm{mg} / \mathrm{L})$ concentration respectively.

\subsection{Design of experiment}

The Design Expert (version 7.0) Software was used to ascertain the number of experiments to be assayed for the optimization of three components (independent variables) comprising contact time (A), $\mathrm{pH}$ (B) and dosage (C) on the removal of $\mathrm{COD}$ and $\mathrm{NH}_{3}-\mathrm{N}$ (dependent parameters). Table 1 shows the Codes, ranges and levels of the different independent variables of contact time, dosage and $\mathrm{pH}$ by the RSM design. The quadratic equation model of the response $Y$ derived for predicting the optimum conditions is a function of the levels of independent variables expressed according to Equation (2):

$$
Y=\beta_{o}+\sum_{i=1}^{k} \beta_{i} \cdot x_{i}+\sum_{i=1}^{k} \beta_{i i} \cdot x_{i}^{2}+\sum_{t_{i}=j}^{k} \sum_{j}^{k} \beta_{i j} \cdot x_{i} \cdot x_{j}+. .+e
$$

where $i$ represents the linear coefficient, $j$ the quadratic coefficient, $\beta$ as the coefficient of regression, $k$ is for the amount of factors studied and optimized by the experiment while $e$ stands for the random error [20,21]. 
Table 1. Codes, ranges and levels of independent variables of Contact time, dosage and $\mathrm{pH}$ in RSM design

\begin{tabular}{llll}
\hline Factor & Code & Low & High \\
\hline ContactTime & $\mathrm{A}$ & 5 & 120 \\
Dosage & $\mathrm{B}$ & 0.5 & 10 \\
$\mathrm{pH}$ & $\mathrm{C}$ & 5 & 8 \\
\hline
\end{tabular}

\section{Results and Discussion}

\subsection{Optimum mix ratio}

The ooptimization solutions by the RSM for mixing ratio between $\mathrm{MP}$ and $\mathrm{ZE}$ in the removal of $\mathrm{COD}$ and ammonia is shown in figure 1 . The interaction between the various mix ratios of the MP and ZE indicated that the removal of COD and NH3-N increased with the increase in zeolite quantity and corresponding reduction in MP in the mixture probably due to the accumulation on the binding sites of the adsorbent by the adsorbate up to a certain maximum limit when there are no further available sites (optimum condition) after which the removal becomes significantly diminished. The optimum was obtained at ratio $24(\mathrm{ZE}): 16(\mathrm{MP})$ which corresponds to $49.18 \%$ and $55.14 \%$ COD and $\mathrm{NH}_{3}-\mathrm{N}$ removal respectively (see table 2). The Values of "Prob $>\mathrm{F}^{\prime}$ is 0.0003 and 0.0042 for $\mathrm{COD}$ and $\mathrm{NH}_{3}-\mathrm{N}$ respectively, which is less than 0.05 indicating that the model terms are significant.

\subsection{Central composite design (CCD)}

In this investigation, three significant factors, contact time (A) adsorbent dose (B) and $\mathrm{pH}(\mathrm{C})$ were designated as independent variables and analysed. Whereas the removal of $\mathrm{COD}\left(\mathrm{Y}_{\mathrm{COD}}\right)$ and ammonia $\left(\mathrm{Y}_{\mathrm{NH} 3-\mathrm{N}}\right)$ were selected as the dependent variable (response) in order to observe the comprehensive components which have the capacity to influence a reduction of $\mathrm{COD}$ and $\mathrm{NH}_{3}-\mathrm{N}$. The percentage reduction as a response to each experimental state was analysed using the RSM as presented in Table 3. The percentage removals ranged from $47.15 \%$ to $70.14 \%$ and $60.43 \%$ to $86.94 \%$ for COD and $\mathrm{NH}_{3}-\mathrm{N}$ respectively. Accordingly, the software package using the function of multiple regression analysis technique offered a quadratic model, the models were selected going by highest order polynomials [22-25]. The quadratic model used for the removal of COD ( $\mathrm{Y}_{C O D}$ ) and $\mathrm{NH}_{3}-\mathrm{N}\left(\mathrm{Y}_{N H 3-N}\right)$ was represented as follows:

$$
\begin{aligned}
& \mathrm{Y}_{C O D}=69.13+2.07 * \mathrm{~A}-0.41 * \mathrm{~B}-2.31 * \mathrm{C}+ \\
& 0.57 * \mathrm{~A} * \mathrm{~B}-2.07 * \mathrm{~A} * \mathrm{C}+0.99 * \mathrm{~B} * \mathrm{C}-2.03 * \mathrm{~A}^{2}- \\
& 1.47 * \mathrm{~B}^{2}-6.45 * \mathrm{C}^{2} \\
& \quad \mathrm{Y}_{N H 3-N}=82.62-1.99 * \mathrm{~A}+1.72 * \mathrm{~B}+3.74 * \mathrm{C}+ \\
& 3.70 * \mathrm{~A} * \mathrm{~B}-2.50 * \mathrm{~A} * \mathrm{C}-0.59 * \mathrm{~B} * \mathrm{C}-0.64 * \mathrm{~A}^{2}- \\
& 0.50 * \mathrm{~B}^{2}-5.73 * \mathrm{C}^{2}
\end{aligned}
$$

\subsection{Statistical analysis \\ 3.2.1 Analysis of variance}

The regression coefficients for reducing COD and $\mathrm{NH}_{3}-\mathrm{N}$ in the leachate at the end of the adsorption process are presented in Table 4. The calculation of the regression coefficients of the linear and quadratic, as well as the interaction between the factors in the model, was conducted using the least square method. The effect of each independent factor was considered significant at Pvalue $<0.05$ and $95 \%$ of the confidence level. From Table 4, the F-value of the COD model was found to be 267.15, whereas the $\mathrm{F}$-value for $\mathrm{NH}_{3}-\mathrm{N}$ was 110.75 . Low error probability value $[($ Prob $>$ F $)<0.0001]$ demonstrated that the generated models are statistically significant for representing the observed experimental data. Model with higher coefficient of determination value, $\mathrm{R}^{2}(\mathrm{R} 2=$ 0.9959 for COD and $\mathrm{R}^{2}=0.9901$ for $\mathrm{NH}_{3}-\mathrm{N}$ ) can have high levels of multi collinearity which authenticate the obtained regression models. It can be seen that the standard deviation and coefficient of variation of the model are quite low and acceptable. A high adjusted $\mathrm{R}^{2}$ value of 0.9921 for $\mathrm{COD}$ and 0.9811 for $\mathrm{NH}_{3}-\mathrm{N}$ show the models are adequate to predict the removal in different process condition. The validity of the models was demonstrated by the "Lack of Fit F-value" of 0.62 (COD removal) and $0.4\left(\mathrm{NH}_{3}-\mathrm{N}\right.$ removal) implying the Lack of Fit is not significant and the models fit well to predict the removal. The results also found that one of the examined factors (time) have a positive significant linear effect on the reduction of COD (see equation 3), while dosage and $\mathrm{pH}$ have a negative significant effect which means that the increasing of dosage and $\mathrm{pH}$ affects or reduces the efficiency of the adsorption process. In contrast, for $\mathrm{NH}_{3}-\mathrm{N}$, two factors (dosage and $\mathrm{pH}$ ) have a positive significant effect on the removal and contact time exhibits negative effect, indicating as the contact time increases (see equation 4), adsorption decreases depending on the behaviour of the adsorbent to adsorbate interaction [6,20,21].

Other significant model terms are $\mathrm{A}, \mathrm{B}, \mathrm{C}, \mathrm{AB}, \mathrm{AC}$, $\mathrm{BC}, \mathrm{A}^{2}, \mathrm{~B}^{2}$ and $\mathrm{C}^{2}$ are attained because of the interactions in system by the variable factors. Considering table 4 . all the terms are significant for COD removal and A, B, C, $\mathrm{AB}, \mathrm{AC}$ and $\mathrm{C}^{2}$ are significant for $\mathrm{NH} 3-\mathrm{N}$ removal. This can be recognized base on the P-values less than 0.05 which implies the significant variable quantity at $95 \%$ confidence limit. Significant terms are having larger $\mathrm{F}$ value while the insignificant terms have smaller $F$ value, and apparently the variable having the most significant effect in the removal of COD were the quadratic term $\mathrm{C}^{2}$ $(\mathrm{F}$ value $=1731.24)$ followed by the liner term $\mathrm{pH}(\mathrm{F}$ value $=210.03)$ and quadratic $\mathrm{A}^{2}(\mathrm{~F}$ value $=99.81)$. Similarly for NH3-N removal the most significant terms are the quadratic term $\mathrm{C}^{2}(\mathrm{~F}$ value $=516.73)$ followed by the linear terms $\mathrm{pH}(\mathrm{F}$ value 208.35) and $\mathrm{AB}(\mathrm{F}$ value $=$ 119.29). Hence, as suggested by the ANOVA $\mathrm{pH}$ and contact time were the most instrumental operating factors for COD and comparatively for $\mathrm{NH}_{3}-\mathrm{N}$ removal $\mathrm{pH}$ and the coupled contact time and dosage term are influential in the study. 

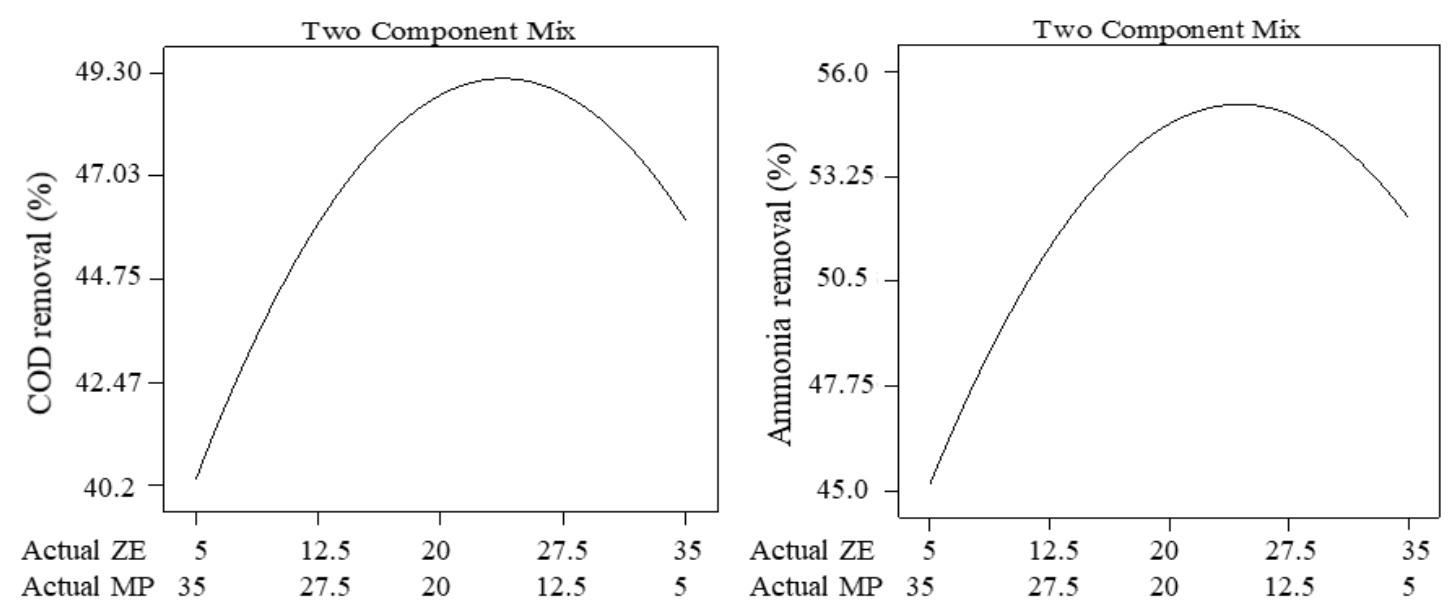

Figure 1. Optimization solutions response for mixing ratio between MP and ZE by the removal of COD and ammonia.

Table 2. Mixing ratio optimization solution between moringa leaf powder and zeolite

\begin{tabular}{lllllll}
$\begin{array}{l}\text { Solutions } \\
\text { Number }\end{array}$ & ZE $(\mathrm{g})$ & MP $(\mathrm{g})$ & $\begin{array}{l}\text { COD } \\
(\%)\end{array}$ & $\begin{array}{l}\text { Ammonia } \\
(\%)\end{array}$ & \multicolumn{2}{l}{ Desirability } \\
\hline 1 & 24 & 16 & 49.18 & 55.14 & 0.966 & Selected \\
\hline
\end{tabular}

Table 3 CCD of two variables and their responses.

\begin{tabular}{|c|c|c|c|c|c|c|c|}
\hline \multirow[t]{2}{*}{ Run } & \multirow{2}{*}{$\begin{array}{c}\text { Factor } 1 \\
\text { A:Contact Time } \\
\text { mins } \\
\end{array}$} & \multirow{2}{*}{$\begin{array}{c}\text { Factor } 2 \\
\text { B:Dosage } \\
\mathrm{mg} / \mathrm{L} \\
\end{array}$} & \multirow[t]{2}{*}{$\begin{array}{c}\text { Factor } 3 \\
\text { C:pH }\end{array}$} & \multicolumn{2}{|c|}{$\begin{array}{c}\text { Response } 1 \\
\text { COD }(\%)\end{array}$} & \multicolumn{2}{|c|}{$\begin{array}{l}\text { Response } 2 \\
\mathrm{NH}_{3}-\mathrm{N}(\%) \\
\end{array}$} \\
\hline & & & & Actual & Predicted & Actual & Predicted \\
\hline 1 & 62.5 & 13.24 & 6.5 & 64.25 & 64.28 & 84.42 & 84.1 \\
\hline 2 & 62.5 & 5.25 & 3.98 & 54.54 & 54.77 & 60.43 & 60.12 \\
\hline 3 & 120 & 10 & 5 & 65.19 & 64.8 & 77.75 & 78.53 \\
\hline 4 & 62.5 & 5.25 & 6.5 & 68.5 & 69.13 & 81.26 & 82.62 \\
\hline 5 & 62.5 & 5.25 & 6.5 & 69.33 & 69.13 & 81.96 & 82.62 \\
\hline 6 & 120 & 10 & 8 & 57.87 & 58.03 & 79.97 & 79.82 \\
\hline 7 & 5 & 10 & 8 & 56.95 & 56.89 & 80.87 & 81.42 \\
\hline 8 & 62.5 & 5.25 & 9.02 & 47.15 & 47.01 & 72.93 & 72.7 \\
\hline 9 & 62.5 & 5.25 & 6.5 & 70.14 & 69.13 & 83.79 & 82.62 \\
\hline 10 & 120 & 0.5 & 5 & 66.48 & 66.47 & 66.67 & 66.51 \\
\hline 11 & 62.5 & 5.25 & 6.5 & 68.36 & 69.13 & 81.49 & 82.62 \\
\hline 12 & 159.2 & 5.25 & 6.5 & 66.72 & 66.89 & 77.98 & 77.45 \\
\hline 13 & 5 & 10 & 5 & 55.2 & 55.38 & 70.45 & 70.13 \\
\hline 14 & 5 & 0.5 & 5 & 59.55 & 59.32 & 72.35 & 72.89 \\
\hline 15 & 34.2 & 5.25 & 6.5 & 68.46 & 67.62 & 83.61 & 83.45 \\
\hline 16 & 62.5 & 5.25 & 6.5 & 68.98 & 69.13 & 83.74 & 82.62 \\
\hline 17 & 5 & 0.5 & 8 & 56.54 & 56.86 & 86.94 & 86.55 \\
\hline 18 & 62.5 & 2.74 & 6.5 & 65.59 & 65.66 & 78.53 & 78.31 \\
\hline 19 & 120 & 0.5 & 8 & 55.98 & 55.73 & 69.46 & 70.17 \\
\hline 20 & 62.5 & 5.25 & 6.5 & 68.75 & 69.13 & 83.23 & 82.62 \\
\hline
\end{tabular}




\begin{tabular}{|c|c|c|c|c|c|c|c|c|}
\hline \multirow{3}{*}{ Source } & ANOVA & for & Response & Irface & Quadratic & Model & COD & and \\
\hline & \multicolumn{2}{|c|}{ Sum of Squares } & \multicolumn{2}{|c|}{ Mean Square } & \multicolumn{2}{|c|}{ F Value } & \multicolumn{2}{|l|}{ p-value } \\
\hline & COD & $\mathrm{NH}_{3}-\mathrm{N}$ & COD & $\mathrm{NH}_{3}-\mathrm{N}$ & COD & $\mathrm{NH}_{3}-\mathrm{N}$ & COD & $\mathrm{NH}_{3}-\mathrm{N}$ \\
\hline Model & 832.19 & 912.63 & 92.47 & 101.4 & 267.15 & 110.75 & $<0.0001$ & $<0.0001$ \\
\hline A-Contact Time & 1 & 36.83 & 39.79 & 36.83 & 114.96 & 40.23 & $<0.0001$ & $<0.0001$ \\
\hline B-Dosage & 2.29 & 40.53 & 2.29 & 40.53 & 6.62 & 44.26 & 0.0278 & $<0.0001$ \\
\hline $\mathrm{C}-\mathrm{pH}$ & 72.69 & 190.77 & 72.69 & 190.77 & 210.03 & 208.35 & $<0.0001$ & $<0.0001$ \\
\hline $\mathrm{AB}$ & 2.58 & 109.22 & 2.58 & 109.22 & 7.44 & 119.29 & 0.0213 & $<0.0001$ \\
\hline $\mathrm{AC}$ & 34.28 & 50 & 34.28 & 50 & 99.04 & 54.61 & $<0.0001$ & $<0.0001$ \\
\hline $\mathrm{BC}$ & 7.88 & 2.81 & 7.88 & 2.81 & 22.77 & 3.07 & 0.0008 & 0.1104 \\
\hline $\mathrm{A}^{2}$ & 34.55 & 3.44 & 34.55 & 3.44 & 99.81 & 3.76 & $<0.0001$ & 0.0811 \\
\hline $\mathrm{B}^{2}$ & 31.26 & 3.6 & 31.26 & 3.6 & 90.31 & 3.93 & $<0.0001$ & 0.0755 \\
\hline $\mathrm{C}^{2}$ & 599.21 & 473.12 & 599.21 & 473.12 & 1731.24 & 516.73 & $<0.0001$ & $<0.0001$ \\
\hline Residual & 3.46 & 9.16 & 0.35 & 0.92 & & & & \\
\hline Lack of Fit & 1.33 & 2.61 & 0.27 & 0.52 & 0.62 & 0.4 & 0.6909 & 0.8323 \\
\hline \multirow[t]{2}{*}{ Pure Error } & 2.13 & 6.55 & 0.43 & 1.31 & & & & \\
\hline & \multicolumn{2}{|c|}{ COD } & \multicolumn{2}{|l|}{$\mathrm{NH}_{3}-\mathrm{N}$} & & & & \\
\hline Std. Dev. & \multicolumn{2}{|c|}{0.59} & 0.96 & & & & & \\
\hline Mean & \multicolumn{2}{|c|}{62.73} & 77.89 & & & & & \\
\hline C.V. \% & \multicolumn{2}{|c|}{0.94} & 1.23 & & & & & \\
\hline R-Squared & \multicolumn{2}{|c|}{0.9959} & 0.9901 & & & & & \\
\hline Adj R-Squared & \multicolumn{2}{|c|}{0.9921} & 0.9811 & & & & & \\
\hline Pred R-Squared & \multicolumn{2}{|c|}{0.9874} & 0.9568 & & & & & \\
\hline Adeq Precision & \multicolumn{2}{|c|}{53.176} & 39.049 & & & & & \\
\hline
\end{tabular}

Fig. 2 demonstrates the plot of the predicted values alongside the actual values, the predicted values were distributed systematically near to the actual responses and this has demonstrated the generated regression models can effectively explain the correlation between the independent variables and the response for the contaminants removal. The data are distributed consistently in a straight line thus the error is insignificant within the bounds of operating parameters.

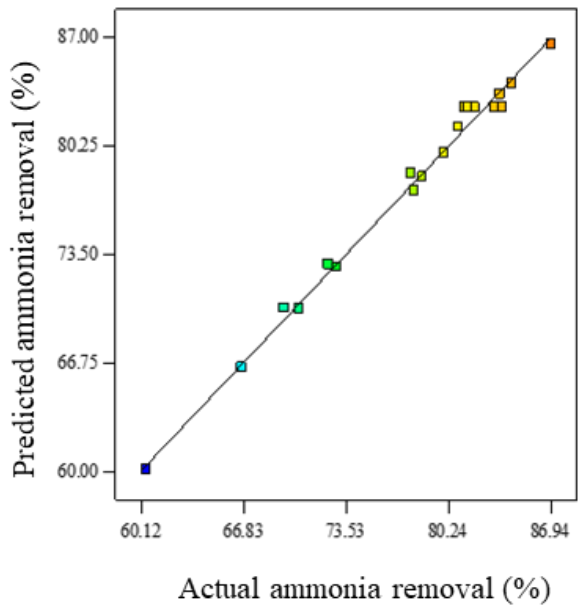

Fig.2 Predicted versus actual values plot for $\mathrm{COD}$ and $\mathrm{NH}_{3}-\mathrm{N}$ removal

Figs. 3 presents the $3 \mathrm{D}$ response surface plots for the removal of $\mathrm{COD}$ and $\mathrm{NH}_{3}-\mathrm{N}$ parameters respectively as a function of contact time and dosage while $\mathrm{pH}$ was set as actual factor ( $\mathrm{pH}$ value 6 ) by the RSM. It can be observed that all of the parameters feature the highest level at the middle region. From both figures, $\mathrm{NH}_{3}-\mathrm{N}$ constituted the better removed variable in the removal process than COD. Similar behavior was observed by Moideen [20] and Daud [24]. 


\subsubsection{Process optimization}

The RSM statistical optimization process was employed to evaluate the optimal response conditions in the space of the controlling factors by taking into consideration the Model F-value that is presented in the model. The lesser and upper bounds of the sequence for all the parameters are enclosed in this optimization process as shown in Fig. 4. The desirability function was administered to suggest an effective method to achieve optimum reaction conditions. Aided by the Design Expert software, varying sets of different optimum operating variables and corresponding parameter removals are generated. The desirability of the optimum solutions is established as 0.917 to represent the accurateness between the experimental results and recommended solutions.
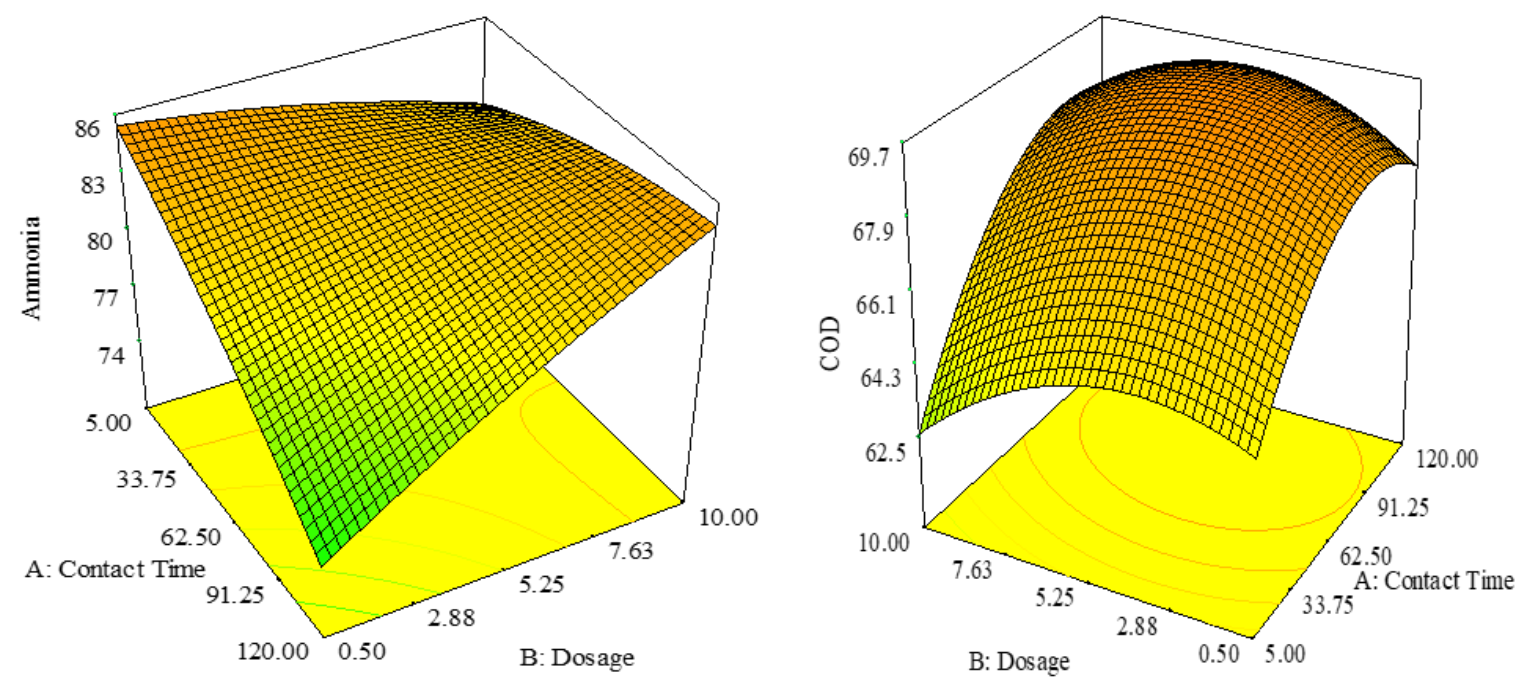

Fig. 3 Response surface plot for $\mathrm{NH}_{3}-\mathrm{N}$ and COD removal

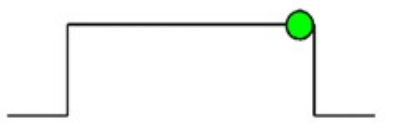

5.00

120.00

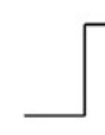

0.50

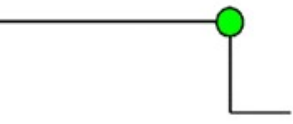

10.00

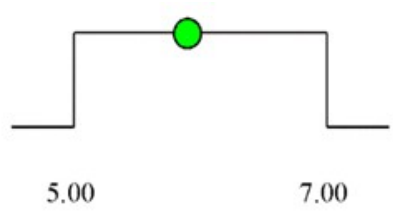

$\mathrm{pH}=5.90$
Contact Time $=113.00$

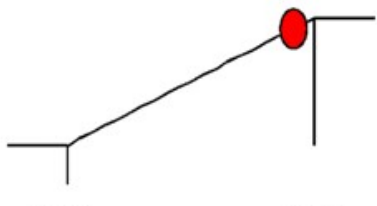

60.43
86.94

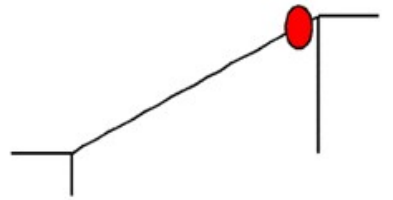

47.15
70.14
Desirability $=0.917$

Ammonia $=84.69$

$\mathrm{COD}=68.30$

Fig. 4 Numerical optimization solution 


\section{Conclusion}

According to the limit criterion for maximization of contaminants removal, the numerical RSM optimization technique was applied to produce several optimum operational process conditions. The optimization of the process parameters improved the optimum adsorption of the response factors. Based on the data obtained from the analysis, ZE:MP mixed ratio was $24: 16$, pH was 5.90, dosage $100 \mathrm{~g} / \mathrm{L}$ and the contact time 113 minutes were suggested to be the optimum condition for COD and $\mathrm{NH}_{3}-\mathrm{N}$ removal. Under the optimum operating conditions, the actual versus predicted parameter removal can achieve around $70.14 \%$ and $86.94 \%$ for actual COD and NH3-N removal respectively and $69.13 \%$ and $86.55 \%$ for the predicted COD and $\mathrm{NH} 3-\mathrm{N}$ removal respectively. RSM is more reliable in predicting the nonlinear relationship between the process variables and response.

\section{Acknowledgement}

The authors would like to acknowledge the Ministry of Higher Education, Malaysia, Living Micro Corporation Sdn. Bhd. and Universiti Tun Hussein Onn Malaysia for financial support under Fundamental Research Grant (FRGS) No. 1457, Endownment Research Grant No. A128 and MyBrain15 (MyPhD).

\section{References}

[1] Foo, K. Y., \& Hameed, B. H. (2009). Utilization of rice husk ash as novel adsorbent: a judicious recycling of the colloidal agricultural waste. Advances in Colloid and Interface Science, 152(1), 39-47..

[2] Othman, Norzila, Y. S. Kueh, F. H. AzizulRahman, and Rafidah Hamdan (2014). Watermelon rind: a potential adsorbent for zinc removal. Applied Mechanics and Materials, 680 , 146-149.

[3] Daud, Z., Abubakar, M. H., Kadir, A. A., Latiff, A. A. A., Awang, H., Halim, A. A., \& Marto, A. (2017). Batch study on cod and ammonia nitrogen removal using granular activated carbon and cockle shells. IJE TRANSACTIONS A: Basics, 30, 937-944.

[4] Daud, Z., Hatta, M. Z. M., Kassim, A. S. M., Awang, H., \& Aripin, A. M. (2014). Exploring of agro waste (pineapple leaf, corn stalk, and napier grass) by chemical composition and morphological study. BioResources, 9(1), 872880. http://doi.org/10.15376/biores.9.1.872-880.

[5] Adeleke, A. R. O., Abdul Latiff, A. A., Daud, Z., Ridzuan, B., and Mat Daud, N. F. (2016). Remediation of Raw Wastewater of Palm Oil Mill Using Activated Cow Bone Powder through Batch Adsorption \&lt;sup\&gt;\&lt;/sup\&gt; Key Engineering Materials, 705, 380-384. http://doi.org/10.4028/www.scientific.net/KEM. 705.380
[6] Adeleke A.O., Ab Aziz Ab Laatiff, A.A AlGheethi., and Zawawi D. (2017). Optimization of operating paramters of novel composite adsorbent for organic pollutant removal from POME using response surface methodology. Chemosphere, 174, 232-242. http://doi.org/10.1016

[7] Habeeb, S. A., Latiff, A. A. A., Daud, Z., and Ahmad, Z. (2011). The start-up of hybrid, anaerobic up-flow sludge blanket (HUASB) under a range of mesophiclic and thermophilic temperatures. EnvironmentAsia, 4(2). http://doi.org/10.14456/ea.2011.19

[8] Rahaman, A. A., Latif, A. A. A., Daud, Z., Ridzuan, M., and Jagaba, A. . (2016). Preparation and Characterization of Activated Cow Bone Powder for the Adsorption of Cadmium from Palm Oil Mill Effluent. Materials Science and Engineering, 136(July), 1-6. $\quad$ http://doi.org/10.1088/1757$\underline{899 X / 136 / 1 / 012045}$

[9] Bello, O. S., Adegoke, K. A., \& Akinyunni, O. O. (2017). Preparation and characterization of a novel adsorbent from Moringa oleifera leaf. Applied Water Science, 7(3), 1295-1305.

[10]Ali, E. N., Alfarra, S. R., Yusoff, M. M., \& Rahman, M. L. (2015). Environmentally friendly biosorbent from Moringa oleifera leaves for water treatment. International Journal of Environmental Science and Development, 6(3), 165.

[11] Jiraungkoorskul, K., \& Jiraungkoorskul, W. (2016). Moringa oleifera: A new challenge reducing heavy metal toxicity: A review. Indian Journal of Agricultural Research, 50(3).

[12] Mohamed, R., Al-Gheethi, A., Abdulrahman, A., bin Sainudin, M. S., Bakar, S. A., \& Kassim, A. H. M. (2018). Optimization of Ceramic Waste Filter for Bathroom Greywater Treatment using Central Composite Design (CCD). Journal of Environmental Chemical Engineering.

[13] Adeleke, A. O., Al-Gheethi, A. A., \& Daud, Z. (2017). Optimization of operating parameters of novel composite adsorbent for organic pollutants removal from POME using response surface methodology. Chemosphere, 174, 232-242.

[14] Hauwa, A., Mohamed, R. M. S. R., Al-Gheethi, A. A., Wurochekke, A. A., \& Hashim, M. A. (2017). Harvesting of Botryococcus sp. biomass from greywater by natural coagulants. Waste and Biomass Valorization, 1-13.

[15] Sadhukhan, B., Mondal, N. K., \& Chattoraj, S. (2016). Optimisation using central composite design (CCD) and the desirability function for sorption of methylene blue from aqueous solution onto Lemna major. Karbala International Journal of Modern Science, 2(3), 145-155.

[16] Tan, Y. H., Abdullah, M. O., Nolasco-hipolito, C., Syuhada, N., \& Zauzi, A. (2017). 
Application of RSM and Taguchi methods for optimizing the transesteri fi cation of waste cooking oil catalyzed by solid ostrich and chicken-eggshell derived $\mathrm{CaO}$. Renewable Energy, 114, 437-447. http://doi.org/10.1016/j.renene.2017.07.024.

[17] Daud, Z., Abubakar, M. H., Kadir, A. A., Aziz, A., Latiff, A., Halim, A. A., \& Marto, A. (2017). Adsorption studies of leachate on cockle shells. International Journal of GEOMATE, 12(29), 4652.

[18] Daud, Z., Hijab Abubakar, M., Abdul Kadir, A., Abdul Latiff, A., Awang, H., Abdul Halim, A., \& Marto, A. (2016). Optimization of Leachate Treatment with Granular Biomedia: Feldspar and Zeolite. Indian Journal of Science and Technology, 9(37), 11-15. http://doi.org/10.17485/ijst/2016/v9i37/91845

[19] Standard methods for the examination of water and wastewater. 2012. Washington, DC: American Public Health Association (APHA).

[20] Siti Nur Fatihah Moideen, Fadhil, M., Rezania, S., Ponraj, M., Rahman, A. A., Wen, L., Zulhilmi, I., Shazwin, M., Yu-you, L., Komori, D. (2017). Dual phase role of composite adsorbents made from cockleshell and natural zeolite in treating river water. Journal of King Saud University - Science, 6-11. http://doi.org/10.1016/j.jksus.2017.06.001

[21] Ghorbani, F., \& Kamari, S. (2017). Application of response surface methodology for optimization of methyl orange adsorption by Fe- grafting sugar beet bagasse. Adsorption Science \& Technology, 35(3-4), 317-338.

[22] Sadhukhan, B., Mondal, N. K., \& Chattoraj, S. (2016). Optimisation using central composite design ( CCD ) and the desirability function for sorption of methylene blue from aqueous solution onto Lemna major. Karbala International Journal of Modern Science, 2(3), 145-155. http://doi.org/10.1016/j.kijoms.2016.03.005.

[23] Halim, Azhar Abdul, Kee Ke Han, and Marlia Mohd Hanafiah (2015). Removal of methylene blue from dye wastewater using river sand by adsorption. Nature Environment and Pollution Technology 14, no. 1, 89.

[24]Daud, Z., Nasir, N., Aziz Abdul Latiff, A., Ridzuan, M. B., \& Awang, H. (2016). Treatment of biodiesel wastewater by coagulationflocculation process using polyaluminium chloride (PAC) and polyelectrolyte anionic. ARPN Journal of Engineering and Applied Sciences, 11(20), 11855-11859.

[25] Daud, Z., Abubakar, M. H., Kadir, A. A., Latiff, A. A. A., Awang, H., Halim, A. A., \& Marto, A. (2017). Batch study on cod and ammonia nitrogen removal using granular activated carbon and cockle shells. IJE TRANSACTIONS A: Basics, 30, 937-944.. 